\title{
Formation of todorokite
} from " $c$-disordered" $\mathrm{H}^{+}$-birnessites: the roles of average manganese oxidation state and interlayer cations

\author{
Huaiyan Zhao, Xinran Liang, Hui Yin, Fan Liu, Wenfeng Tan, Guohong Qiu and Xionghan Feng*
}

\begin{abstract}
Background: Todorokite, a $3 \times 3$ tectomanganate, is one of three main manganese oxide minerals in marine nodules and can be used as an active $\mathrm{MnO}_{6}$ octahedral molecular sieve. The formation of todorokite is closely associated with the poorly crystalline phyllomanganates in nature. However, the effect of the preparative parameters on the transformation of "c-disordered" $\mathrm{H}^{+}$-birnessites, analogue to natural phyllomanganates, into todorokite has not yet been explored.

Results: Synthesis of " $\mathrm{C}$-disordered" $\mathrm{H}^{+}$-birnessites with different average manganese oxidation states (AOS) was performed by controlling the $\mathrm{MnO}_{4}{ }^{-} / \mathrm{Mn}^{2+}$ ratio in low-concentrated $\mathrm{NaOH}$ or $\mathrm{KOH}$ media. Further transformation to todorokite, using " $\mathrm{C}$-disordered" $\mathrm{H}^{+}$-birnessites pre-exchanged with $\mathrm{Na}^{+}$or $\mathrm{K}^{+}$or not before exchange with $\mathrm{Mg}^{2+}$, was conducted under reflux conditions to investigate the effects of Mn AOS and interlayer cations. The results show that all of these " $c$-disordered" $\mathrm{H}^{+}$-birnessites exhibit hexagonal layer symmetry and can be transformed into todorokite to different extents. "c-disordered" $\mathrm{H}^{+}$-birnessite without pre-exchange treatment contains lower levels of $\mathrm{Na} / \mathrm{K}$ and is preferably transformed into ramsdellite with a smaller $1 \times 2$ tunnel structure rather than todorokite. $\mathrm{Na}^{+} \mathrm{pre}^{-}$ exchange, i.e. to form $\mathrm{Na}-\mathrm{H}$-birnessite, greatly enhances transformation into todorokite, whereas $\mathrm{K}^{+}$pre-exchange, i.e. to form $\mathrm{K}$-H-birnessite, inhibits the transformation. This is because the interlayer $\mathrm{K}^{+}$of birnessite cannot be completely exchanged with $\mathrm{Mg}^{2+}$, which restrains the formation of tunnel "walls" with $1 \mathrm{~nm}$ in length. When the Mn AOS values of $\mathrm{Na}$-H-birnessite increase from 3.58 to 3.74 , the rate and extent of the transformation sharply decrease, indicating that a key process is $\mathrm{Mn}(\mathrm{III})$ species migration from layer into interlayer to form the tunnel structure during todorokite formation.

Conclusions: Structural $\mathrm{Mn}(\mathrm{III})$, together with the content and type of interlayer metal ions, plays a crucial role in the transformation of " $c$-disordered" $\mathrm{H}^{+}$-birnessites with hexagonal symmetry into todorokite. This provides further explanation for the common occurrence of todorokite in the hydrothermal ocean environment, where is usually enriched in large metal ions such as Mg, $\mathrm{Ca}, \mathrm{Ni}$, Co and etc. These results have significant implications for exploring the origin and formation process of todorokite in various geochemical settings and promoting the practical application of todorokite in many fields.
\end{abstract}

Keywords: "c-disordered" $\mathrm{H}^{+}$-birnessite, Todorokite, Average manganese oxidation state, Interlayer cation

\footnotetext{
*Correspondence: fxh73@mail.hzau.edu.cn

Key Laboratory of Arable Land Conservation (Middle and Lower

Reaches of Yangtse River), Ministry of Agriculture, College of Resources

and Environment, Huazhong Agricultural University, Wuhan 430070,

China
}

\section{Chemistry Central}

(c) 2015 Zhao et al. This article is distributed under the terms of the Creative Commons Attribution 4.0 International License (http://creativecommons.org/licenses/by/4.0/), which permits unrestricted use, distribution, and reproduction in any medium, provided you give appropriate credit to the original author(s) and the source, provide a link to the Creative Commons license, and indicate if changes were made. The Creative Commons Public Domain Dedication waiver (http://creativecommons.org/ publicdomain/zero/1.0/) applies to the data made available in this article, unless otherwise stated. 


\section{Background}

Todorokite, a $3 \times 3$ tunnel structure with corner-sharing triple chains of $\mathrm{MnO}_{6}$ octahedra, is a naturally occurring manganese $(\mathrm{Mn})$ oxide found in terrestrial $\mathrm{Mn}$ ore deposits, weathering products of manganese-bearing rocks, and marine Mn nodules [1-3]. Due to the superior characteristics of todorokite in ion exchange, specific surface area, thermal stability and molecule-sized tunnels [4], it has many potential industrial applications as molecular sieves, lithium-manganese-oxide cathode materials, heterogeneous catalysts and sensors [4-8], and it also plays an important role in cleaning up natural water and controlling the concentrations of heavy metals in soil solution [9].

Todorokites are often obtained by hydrothermal treatment or refluxing process from triclinic birnessite with a layered structure $[4,10,11]$. Oxidation of the $\mathrm{Mn}(\mathrm{II})$ located above or below vacant sites facilitates the formation of a stable todorokite-like structure during marine diagenesis and hydrothermal process [12]. Liu et al. [13] proposed that some octahedral Mn(III) from the layers of buserite could migrate into the interlayer and become corner-sharing octahedra that assist in the formation of the "wall" of the tunnels during hydrothermal heat treatment. Cui et al. $[8,14]$ also reported that the formation of todorokite under reflux conditions is closely related to the $\mathrm{Mn}$ (III) content and the content of Mn(III) in birnessite depends partly on the Mn AOS values. The degree of transformation of triclinic birnessite samples to todorokite decreases with the increasing of their $\mathrm{Mn}$ AOS values [8].

Recently Atkins et al. [15] found that "c-disordered" $\mathrm{H}^{+}$-birnessite with a poorly crystalline, hexagonal layer symmetry can also be transformed into todorokite under a mild reflux procedure. In addition, in the natural environment the microbial oxidation products of $\mathrm{Mn}(\mathrm{II})$ are mainly birnessite-like phases exhibiting poor crystallinity and hexagonal symmetry [16-19]. Thus, the formation of todorokite and poorly crystalline phyllomanganates are closely associated in natural marine environments. However, the effect of the preparative parameters on the transformation of " $c$-disordered" $\mathrm{H}^{+}$-birnessites into todorokite has not yet been explored.

Here we prepared "c-disordered" $\mathrm{H}^{+}$-birnessites with different $\mathrm{Mn}$ AOS by controlling the $\mathrm{MnO}_{4}{ }^{-} / \mathrm{Mn}^{2+}$ ratio in low-concentrated $\mathrm{NaOH}$ or $\mathrm{KOH}$ media. The transformation of " $c$-disordered" $\mathrm{H}^{+}$-birnessite to todorokite was achieved under a mild reflux condition, elucidating the roles of Mn AOS and the interlayer $\mathrm{K}^{+}$and $\mathrm{Na}^{+}$of the "c-disordered" $\mathrm{H}^{+}$-birnessite in the transformation. The results are expected to provide clues for understanding the transformation of poorly crystalline phyllomanganates with hexagonal symmetry to todorokite and shed light on the mechanisms of todorokite formation in earth-surface environment.

\section{Experimental methods}

\section{Preparation of "c-disordered" $\mathrm{H}^{+}$-birnessites with different} Mn AOS values

Synthesis of " $c$-disordered" $\mathrm{H}^{+}$-birnessite was performed following the method of Villalobos et al. [17]. A solution of $10 \mathrm{~g}$ of $\mathrm{KMnO}_{4}(0.1977 \mathrm{M})$ in $320 \mathrm{~mL}$ of distilled deionized water (DDW) was added slowly to a solution of $7.33 \mathrm{~g}$ of $\mathrm{NaOH}(0.51 \mathrm{M})$ solution in $360 \mathrm{~mL}$ of DDW while stirring. Subsequently, a solution of $23.26 \mathrm{~g} \mathrm{MnCl}_{2}$ $(0.3673 \mathrm{M})$ in $320 \mathrm{~mL}$ of DDW was added dropwise to the mixture while stirring vigorously to form precipitate. The suspension was left to settle for $4 \mathrm{~h}$, following the supernatant was discarded. The $\mathrm{pH}$ value was 3.1. The remaining slurry was subsequently centrifuged at 10,000 rpm (Neofuge 23R) for $30 \mathrm{~min}$ and the resulting supernatant was discarded. The product was subjected to $\mathrm{NaCl}$ wash or $\mathrm{Na}^{+}$pre-exchange following the procedures reported by Atkins et al. [15]. The centrifuged paste was mixed with $1 \mathrm{M} \mathrm{NaCl}$, shaken for $1 \mathrm{~h}$ and centrifuged, the supernatant was discarded. This process was repeated 5 times. For the last $1 \mathrm{M} \mathrm{NaCl}$ wash the $\mathrm{pH}$ was adjusted to $\mathrm{pH} 8$ via the drop-wise addition of $1 \mathrm{M} \mathrm{NaOH}$ and the suspension was shaken overnight. After centrifuging, the resulting paste was combined with DDW, shaken for $1 \mathrm{~h}$ and centrifuged. This DDW wash cycle was repeated 10 times. Following the final wash, the suspension was dialyzed for 3 days in $43 \times 27 \mathrm{~mm}$ cellulose dialysis tubing. This sample is named $0.52-\mathrm{Na}-\mathrm{H}-\mathrm{Bir}$ in this paper $(0.52$ was the ratio of $\mathrm{Mn}(\mathrm{VII}) / \mathrm{Mn}(\mathrm{II}))$.

The synthesis of $0.42-\mathrm{Na}-\mathrm{H}-\mathrm{Bir}$ and $0.67-\mathrm{Na}-\mathrm{H}-\mathrm{Bir}$ was similar to that of $0.52-\mathrm{Na}-\mathrm{H}-\mathrm{Bir}$, but the amounts added of $\mathrm{MnCl}_{2} \cdot 4 \mathrm{H}_{2} \mathrm{O}$ were $30 \mathrm{~g}(0.4737 \mathrm{M})$ and $18.785 \mathrm{~g}(0.2966 \mathrm{M})$, respectively (the ratio of $\mathrm{Mn}(\mathrm{VII}) /$ $\mathrm{Mn}(\mathrm{II})$ was 0.42 and 0.67 ). The synthesis of $0.52-\mathrm{H}-\mathrm{Bir}$ did not include the $\mathrm{Na}^{+}$pre-exchange. The synthesis of $0.52-\mathrm{K}-\mathrm{H}-\mathrm{Bir}$ was also similar to that of $0.52-\mathrm{Na}-\mathrm{H}-\mathrm{Bir}$, but used $\mathrm{KOH}$ solution as the material for synthesis and $\mathrm{pH}$ adjustment. The $\mathrm{NaCl}$ wash or $\mathrm{Na}^{+}$pre-exchange was replaced by $\mathrm{KCl}$ wash or $\mathrm{K}^{+}$pre-exchange.

\section{Transformation of "c-disordered" $\mathrm{H}^{+}$-birnessite to todorokite}

Transformation of "c-disordered" $\mathrm{H}^{+}$-birnessite into todorokite was following a method adapted from Feng et al. $[11,20]$. Approximately $20 \mathrm{~g}$ of wet "c-disordered" $\mathrm{H}^{+}$-birnessite slurry was dispersed in $1.5 \mathrm{~L}$ of $1 \mathrm{~mol} / \mathrm{L}$ $\mathrm{MgCl}_{2}$ solution. After being fully exchanged for $24 \mathrm{~h}$, the birnessites were converted into buserites (Bus). Birnessite and buserite are all the layer structure Mn oxides (phyllomanganates), and structurally related to each other. The 
former exhibits a $0.7 \mathrm{~nm}$ basal plane spacing due to the presence of single layer of water molecules and interlayer cations between the layers. When hydrated in the suspension or exchanged with larger hydrated cations (for instance, $\mathrm{Mg}^{2+}, \mathrm{Ca}^{2+}$ ), birnessite can be transformed into buserite with expanded basal plane spacing of $1.0 \mathrm{~nm}$ due to double layers of water molecules in the interlayers. In turn, upon drying or heating, buserite can be dehydrated and converted back into birnessite due to loss of one layer of water molecules. Then buserite solids were collected by centrifugation and re-suspended in $400 \mathrm{~mL} 1 \mathrm{~mol} / \mathrm{L}$ $\mathrm{MgCl}_{2}$ solution and transferred to a $1 \mathrm{~L}$ triangular flask connected with a condensation device, then heated to reflux at $100^{\circ} \mathrm{C}$ and maintained at reflux conditions under magnetic stirring. Suspension aliquots were sampled at time intervals of $3,6,9,12,24,48,72 \mathrm{~h}$, and 1 month. The produced minerals were washed until the conductance of the supernatant was below $20 \mu \mathrm{S} / \mathrm{cm}$ and freeze-dried.

\section{Characterization of "c-disordered" $\mathrm{H}^{+}$-birnessites and their products}

XRD data were collected using Ni-filtered $\mathrm{Cu} \mathrm{K} \alpha$ radiation $(\lambda=0.15418 \mathrm{~nm})$ on a Bruker D8 Advance diffractometer equipped with a LynxEye detector. The diffractometer was operated at a tube voltage of $40 \mathrm{kV}$ and a current of $40 \mathrm{~mA}$ with a scanning rate of $10 \% \mathrm{~min}$ at a step size of $0.02^{\circ}$. Both buserite and todorokite have a basal d-spacing of $\sim 1 \mathrm{~nm}$. The former is not stable and can be transformed into the $0.7 \mathrm{~nm}$ phase (birnessite) during heating or dehydrating, whereas the latter has relatively high thermal stability [21]. To eliminate the interference of diffraction peaks of buserite on the identification of todorokite, the oriented samples spread on glass slices for the refluxed products were heated for $10 \mathrm{~h}$ at $140^{\circ} \mathrm{C}$ before $\mathrm{XRD}$ analysis [11].

The chemical composition of the samples was determined as follows: $0.1000 \mathrm{~g}$ of sample was dissolved in $25 \mathrm{~mL}$ of $0.25 \mathrm{~mol} / \mathrm{L} \mathrm{NH}_{2} \mathrm{OH} \cdot \mathrm{HCl}$. The contents of $\mathrm{Na}$ and $\mathrm{K}$ were analyzed by a Varian Vista-MPX ICP-OES and the contents of $\mathrm{Mn}$ and $\mathrm{Mg}$ were measured using atomic absorption spectrophotometer (AAS). The average oxidation state (AOS) of Mn was determined using the oxalic acid-permanganate back-titration method.

Transmission electron microscopy (TEM) and highresolution transmission electron microscopy (HRTEM) analyses of the crystal particles were conducted using a JEM-2100F electron microscope (JEOL, Japan) at an accelerating voltage of $200 \mathrm{kV}$. The samples were dispersed into absolute alcohol and ultrasonically vibrated prior to deposition on a holey carbon film, and then airdried at room temperature.

The IR spectra of samples were recorded on a Bruker Vertex 70 FTIR spectrometer by making pellets with
KBr. Samples were scanned 128 times between 4,000 and $400 \mathrm{~cm}^{-1}$ at a resolution of $4 \mathrm{~cm}^{-1}$.

\section{Results and analysis}

\section{Characterization of synthesized "c-disordered"}

$\mathrm{H}^{+}$-birnessites

The XRD patterns of the synthetic " $c$-disordered" $\mathrm{H}^{+}$birnessites are shown on Figure 1. The 0.42-Na-H-Bir sample has primary characteristic peaks of birnessite at $d$ spacings of $0.72,0.36,0.24$, and $0.14 \mathrm{~nm}$, which originate from the reflections of (001), (002), (100), and (110) planes (JPCDS 43-1456) [15], respectively. As the ratio of $\mathrm{Mn}(\mathrm{VII}) / \mathrm{Mn}$ (II) increases from 0.42 to 0.67 , the 0.72 and $0.36 \mathrm{~nm}$ diffraction peaks gradually disappear, implying a decrease in the stacking period along the $c^{*}$ direction. The $0.52-\mathrm{K}-\mathrm{H}-\mathrm{Bir}$ sample has a visible $0.72 \mathrm{~nm}$ diffraction peak, while this peak is absent in the 0.52-H-Bir sample. All these phases have two $h k 0$ reflections of the (100) and (110) planes at $0.24 \mathrm{~nm}$ and $1.4 \mathrm{~nm}$. The $d 100 / d 110$ peak intensity ratio $(2.44 / 1.41=1.73)$ is close to $\sqrt{3}$, which is in good agreement with that of " $c$-disordered" $\mathrm{H}^{+}$birnessite synthesized by Villalobos et al. [17], indicating a hexagonal symmetry $[22,23]$. This is further confirmed by the symmetrical $0.14 \mathrm{~nm}$ peak of these synthetic "c-disordered" $\mathrm{H}^{+}$-birnessites [23]. The $0.24 \mathrm{~nm}$ peak exhibits a degree of asymmetry on the high-angle side in all " $c$-disordered" $\mathrm{H}^{+}$-birnessites, which is typical of phyllomanganates that lack significant long-range ordering of the sheets $[15,24]$.

Chemical analyses and the average manganese oxidation states (AOS) of the synthetic "c-disordered" $\mathrm{H}^{+}$birnessites are presented in Table 1 . The $\mathrm{Na}^{+}$content of the three types of $\mathrm{Na}-\mathrm{H}$-birnessite increases with the $\mathrm{Mn}(\mathrm{VII}) / \mathrm{Mn}(\mathrm{II})$ ratio increasing, and the content of $\mathrm{K}^{+}$is

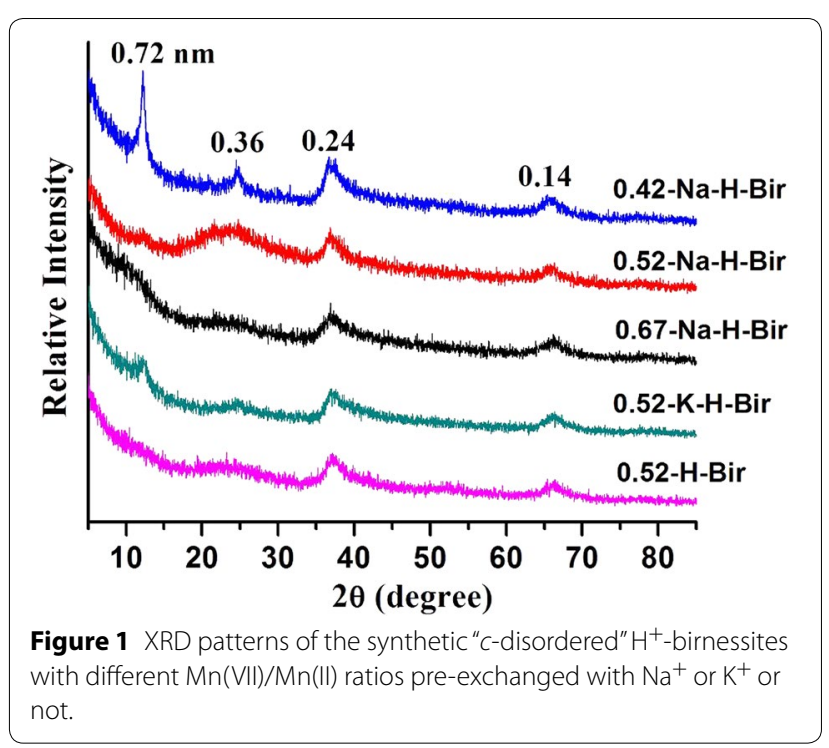


Table 1 Chemical analyses and average manganese oxidation states of the synthetic "c-disordered" $\mathrm{H}^{+}$-birnessites

\begin{tabular}{|c|c|c|c|c|c|c|}
\hline Reaction condition & $\begin{array}{l}\text { Ratio of } \mathrm{MnO}_{4}^{-} / \\
\mathrm{Mn}^{2+}\end{array}$ & Sample & $\mathrm{Na}(\mathrm{mmol} / \mathrm{g})$ & $\mathrm{K}(\mathrm{mmol} / \mathrm{g})$ & $\mathrm{Mn}(\mathrm{mmol} / \mathrm{g})$ & AOS \\
\hline $\mathrm{KMnO}_{4}+\mathrm{NaOH}+\mathrm{MnCl}_{2}(\mathrm{NaCl}$ pre-exchange $)$ & 0.42 & 0.42-Na-H-Bir & 1.61 & 0.20 & 9.84 & 3.58 \\
\hline $\mathrm{KMnO}_{4}+\mathrm{NaOH}+\mathrm{MnCl}_{2}(\mathrm{NaCl}$ pre-exchange $)$ & 0.52 & $0.52-\mathrm{Na}-\mathrm{H}-\mathrm{Bir}$ & 1.64 & 0.03 & 9.68 & 3.63 \\
\hline $\mathrm{KMnO}_{4}+\mathrm{NaOH}+\mathrm{MnCl}_{2}(\mathrm{NaCl}$ pre-exchange $)$ & 0.67 & 0.67-Na-H-Bir & 2.29 & 0.05 & 8.78 & 3.74 \\
\hline $\mathrm{KMnO}_{4}+\mathrm{NaOH}+\mathrm{MnCl}_{2}(\mathrm{KCl}$ pre-exchange $)$ & 0.52 & 0.52-K-H-Bir & 0.01 & 2.43 & 9.15 & 3.66 \\
\hline $\mathrm{KMnO}_{4}+\mathrm{NaOH}+\mathrm{MnCl}_{2}$ & 0.52 & $0.52-\mathrm{H}-\mathrm{Bir}$ & 0.07 & 0.61 & 9.56 & 3.64 \\
\hline
\end{tabular}

far lower than that of $\mathrm{Na}^{+}$in the birnessite samples preexchanged with $\mathrm{Na}^{+}$. The Mn contents of these $\mathrm{Na}-\mathrm{H}-$ birnessites decrease and the Mn AOS values increase as the $\mathrm{Mn}(\mathrm{VII}) / \mathrm{Mn}(\mathrm{II})$ ratio increases. When the $\mathrm{Mn}(\mathrm{VII}) /$ $\mathrm{Mn}$ (II) ratio is $0.42,0.52$ and 0.67 , the Mn AOS values are $3.58,3.63$, and 3.74 , respectively. The $\mathrm{Na}^{+}$contents in $0.52-\mathrm{K}-\mathrm{H}-\mathrm{Bir}$ and $0.52-\mathrm{H}-\mathrm{Bir}$ samples are very low, but the $\mathrm{K}^{+}$content is considerably higher than the $\mathrm{Na}^{+}$ content in the $0.52-\mathrm{K}-\mathrm{H}$-Bir sample and the $\mathrm{K}^{+}$content in $0.52-\mathrm{H}-\mathrm{Bir}$ is one-quarter of that in the $0.52-\mathrm{K}-\mathrm{H}-\mathrm{Bir}$ sample. The Mn contents and AOS values of these two samples are close to that of the $0.52-\mathrm{Na}-\mathrm{H}$-Bir sample.

HR-TEM images of " $c$-disordered" Na-H-birnessites with different $\mathrm{Mn}(\mathrm{VII}) / \mathrm{Mn}(\mathrm{II})$ ratios are presented in Figure 2. The 0.42-Na-H-Bir sample contains aggregations of platy crystals with large size and multiple stacked layers (Figure 2a, b). The fringes of layer stacking are arranged along the $c$-axis direction (001), up to more than $10 \mathrm{~nm}$ stacking thickness with $\sim 0.72 \mathrm{~nm}$ interlayer spacing. In addition, bending or curling of the layers, as reported in $\delta-\mathrm{MnO}_{2}[25,26]$, can also be clearly seen. When the $\mathrm{Mn}(\mathrm{VII}) / \mathrm{Mn}(\mathrm{II})$ ratio of $\mathrm{Na}-\mathrm{H}$-birnessite increases to 0.52 , the birnessite consists of aggregations of small, thin plate-like crystals (Figure 2c, d), with a layer stacking thickness of $\sim 5 \mathrm{~nm}$. When the $\mathrm{Mn}(\mathrm{VII}) /$ $\mathrm{Mn}$ (II) ratio of $\mathrm{Na}-\mathrm{H}$-birnessite increases to 0.67 , the material formed even smaller and thinner platy crystals that are tightly aggregated together, and stacked layers of less than $5 \mathrm{~nm}$ are hardly observed (Figure 2e, f). Therefore, it is suggested that the crystallite sizes of the " $c$-disordered" $\mathrm{Na}$-H-birnessites decrease with increasing $\mathrm{Mn}$ AOS, or with an increasing ratio of $\mathrm{Mn}$ (VII)/Mn(II) during synthesis.

The IR spectra of all synthetic "c-disordered" $\mathrm{Na}-\mathrm{H}$ birnessite samples in the range from 1,400 to $400 \mathrm{~cm}^{-1}$ are shown in Figure 3. The IR absorption bands around 500 and $450 \mathrm{~cm}^{-1}$ are diagnostic for the birnessite structure [10, 27-30]. The "c-disordered" Na-H-birnessites have two main IR bands at around 519 and $456 \mathrm{~cm}^{-1}$ (Figure 3a), which are in good agreement with the characteristic IR bands of birnessites. For different Mn(VII)/ $\mathrm{Mn}$ (II) ratios of " $c$-disordered" $\mathrm{Na}-\mathrm{H}$-birnessites, the position of the characteristic adsorbed bands scarcely change, while the intensity becomes weaker as the Mn AOS value increases. Because the IR bands between 400 and $800 \mathrm{~cm}^{-1}$ can be assigned to $\mathrm{Mn}-\mathrm{O}$ lattice vibration, changes in the position and intensity of these characteristic adsorbed bands can be attributed to changes in the sub-structure of the $\mathrm{MnO}_{6}$ octahedral layer [8]. In addition, the intensity of the adsorbed bands may be related to the crystallinity of the synthetic " $c$-disordered" $\mathrm{Na}-\mathrm{H}$ birnessites. With decreases in Mn AOS value of " $c$-disordered" Na-H-birnessites, the IR bands become stronger (Figure 3), indicating increasing crystallinity. This is consistent with the XRD and TEM results.

\section{Transformation from "c-disordered" $\mathrm{H}^{+}$-birnessite to buserite and todorokite}

Golden et al. [10] reported that certain divalent cations, such as $\mathrm{Mg}^{2+}, \mathrm{Ca}^{2+}$, and $\mathrm{Ni}^{2+}$, possess larger hydrated ion radii and higher hydration energies compared to alkaline metal ions $\left(\mathrm{Na}^{+}, \mathrm{K}^{+}\right.$, etc.). Therefore these divalent cations, through ion exchange, can readily expand the $0.7 \mathrm{~nm}$ basal plane spacing of birnessite to $1.0 \mathrm{~nm}$ of buserite which can be stabilized in the high humidity. After $\mathrm{Mg}^{2+}$-exchanged for $24 \mathrm{~h}$, the birnessites were converted into buserites. The XRD patterns of $\mathrm{Mg}^{2+}$. exchanged " $c$-disordered" $\mathrm{H}^{+}$-birnessites are similar to those of their precursors (Figure 4). All XRD patterns of buserites have 0.24 and $0.14 \mathrm{~nm}$ diffraction peaks, and 0.42-Na-H-Bus $\left(\mathrm{Mg}^{2+}\right.$-exchanged 0.42-Na-H-Bir) has an additional weak $0.72 \mathrm{~nm}$ reflection. The elemental composition indicates that nearly all the interlayer $\mathrm{Na}^{+}$in "c-disordered" $\mathrm{H}^{+}$-birnessites is completely replaced by $\mathrm{Mg}^{2+}$, but in the 0.52-K-H-Bus and 0.52-H-Bus samples, part of the interlayer $\mathrm{K}^{+}, 12.6$ and $18.9 \%$, respectively, is not replaced by $\mathrm{Mg}^{2+}$ (Table 2). The $\mathrm{Mg}^{2+}$ contents of these $\mathrm{Na}-\mathrm{H}$-buserites increase and the Mn contents decrease with increasing $\mathrm{Mn}(\mathrm{VII}) / \mathrm{Mn}$ (II) ratio during synthesis (Table 2).

Over the course of the reflux treatment of $0.42-\mathrm{Na}-\mathrm{H}-$ Bus, the characteristic diffraction peaks of todorokite appear at $3 \mathrm{~h}$ in the XRD pattern (Figure 4a). With reflux time prolonged to $48 \mathrm{~h}$, the peaks of birnessite 

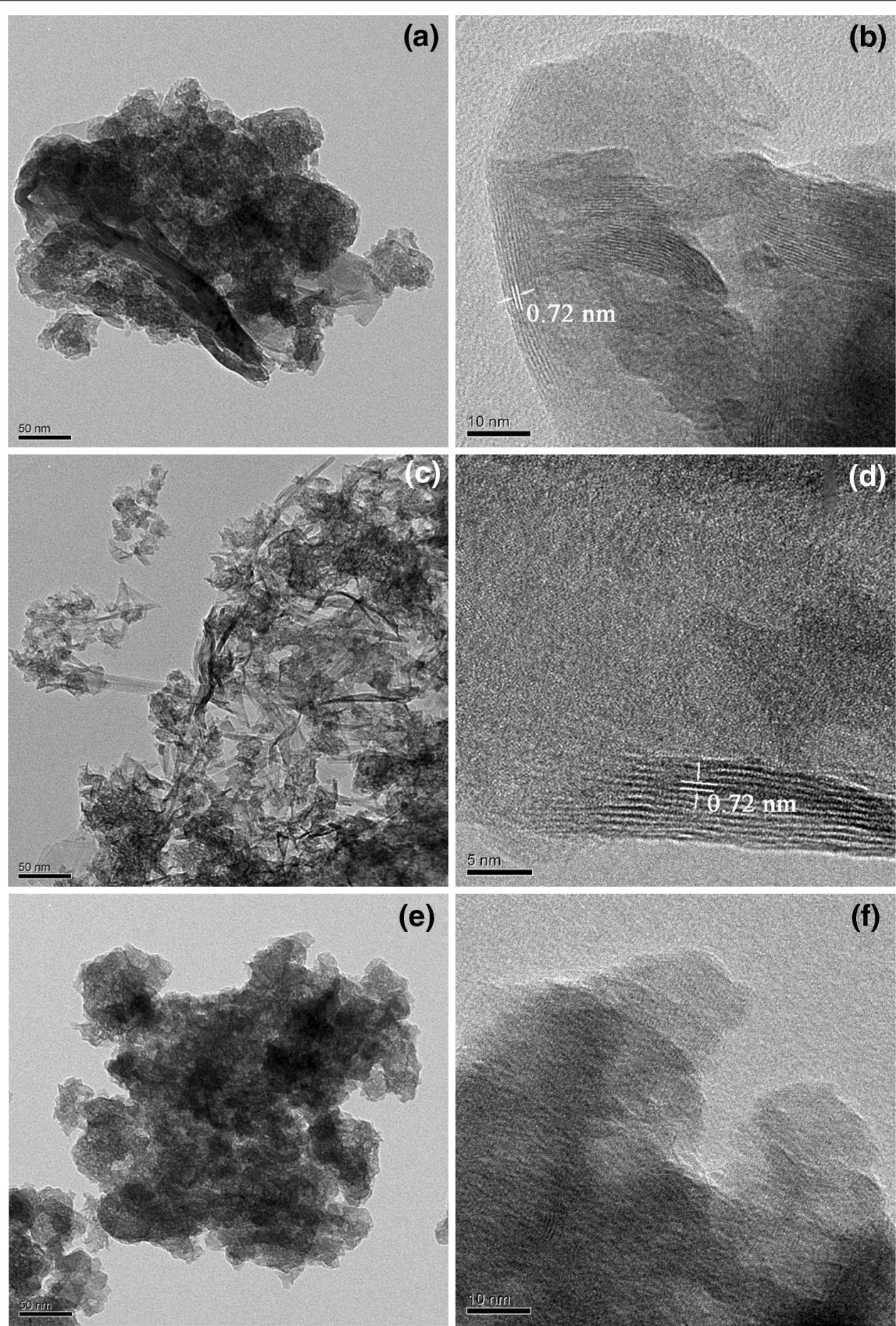

Figure 2 HR-TEM images of "c-disordered" Na-H-birnessites with different Mn(VII)/Mn(II) ratios. a, b 0.42-Na-H-Bir; c, d 0.52-Na-H-Bir; e, f 0.67-Na-HBir.

disappear leaving only strong todorokite XRD reflections, indicating that the $0.42-\mathrm{Na}-\mathrm{H}-\mathrm{Bus}$ has been completely converted to todorokite. With a prolonged reflux time of 1 month, a very weak diffraction peak of manganite at $0.34 \mathrm{~nm}$ appears besides slightly strengthened those of todorokite (Figure 4a). For the 0.52-Na$\mathrm{H}$-Bus sample under reflux treatment, broad todorokite peaks and a very weak birnessite peak are present in the 

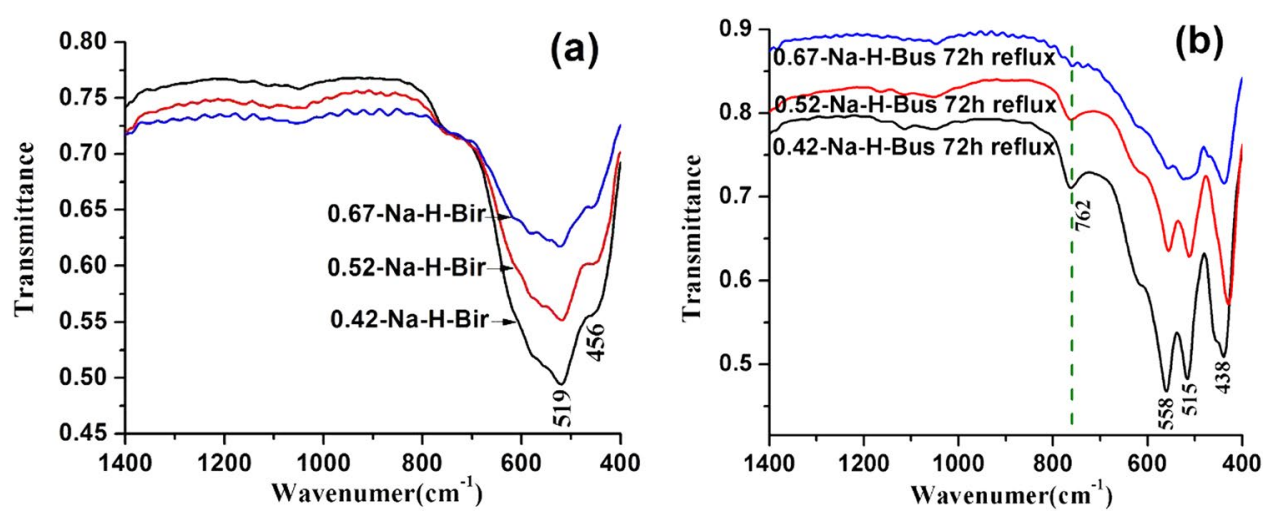

Figure 3 FTIR spectra of "c-disordered" $\mathrm{Na}$-H-birnessites with different $\mathrm{Mn}(\mathrm{VII}) / \mathrm{Mn}(\mathrm{II})$ ratios (a) and their products after Mg-exchange and reflux treatment for $72 \mathrm{~h}(\mathbf{b})$.
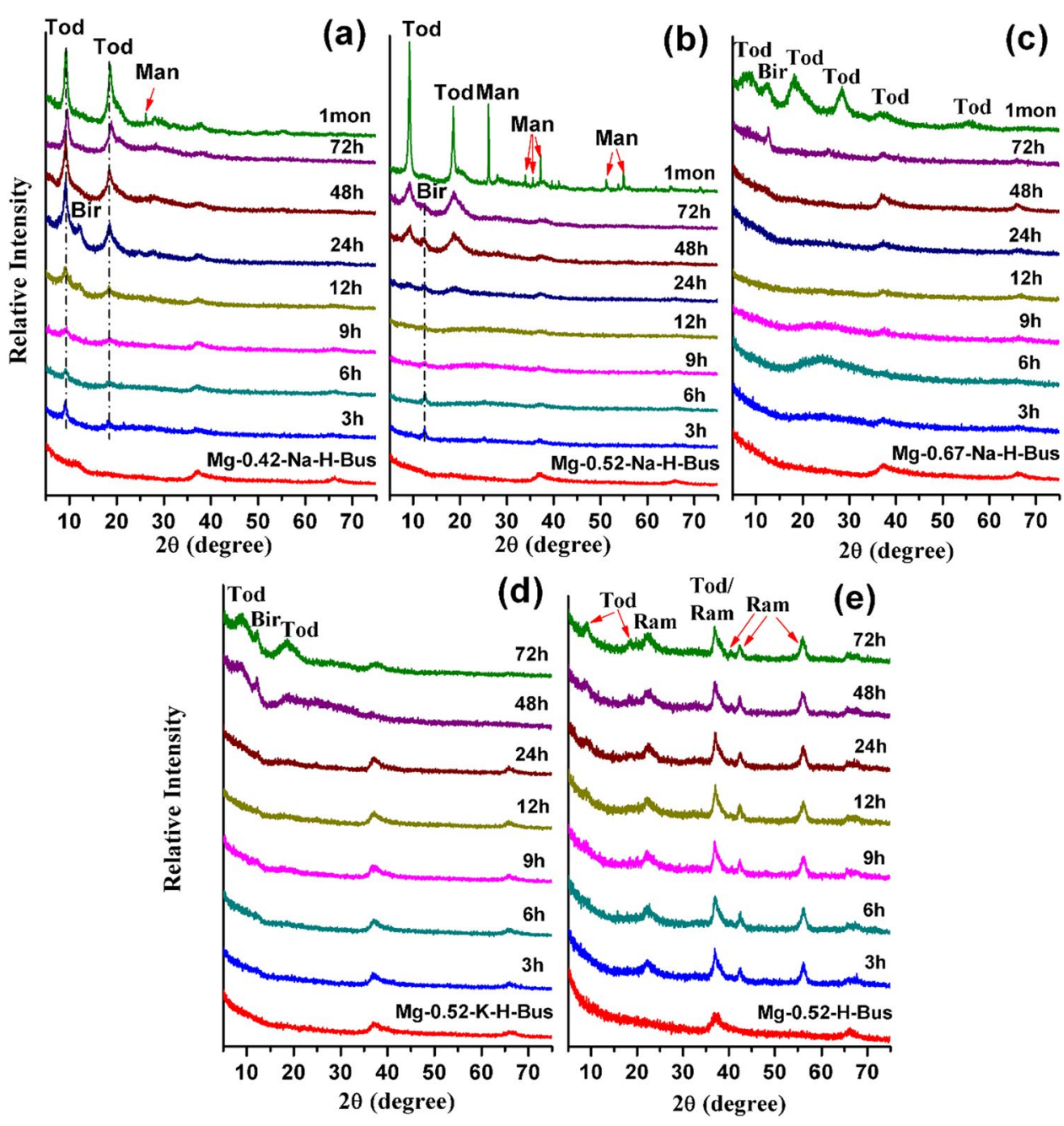

Figure 4 XRD patterns of $\mathrm{Mg}^{2+}$-exchanged intermediates and reflux products for the synthetic " $c$-disordered" $\mathrm{H}^{+}$-birnessites at different times. a 0.42-Na-H-Bir, b 0.52-Na-H-Bir, c 0.67-Na-H-Bir, d 0.52-K-H-Bir, e 0.52-H-Bir. Tod todorokite, Bir birnessite, Man manganite, Ram ramsdellite. 
Table 2 Elemental compositions of the synthetic "c-disordered" $\mathrm{H}^{+}$-birnessites after exchanged with $\mathrm{Mg}^{2+}$ for $^{24} \mathrm{~h}$

\begin{tabular}{llllllll}
\hline Sample & $\mathbf{N a}(\mathbf{m m o l} / \mathbf{g})$ & $\mathbf{K}(\mathbf{m m o l} / \mathbf{g})$ & $\mathbf{M g}(\mathbf{m m o l} / \mathbf{g})$ & $\mathbf{M n}(\mathbf{m m o l} / \mathbf{g})$ & $\mathbf{K} / \mathbf{M n}$ & $\mathbf{M g} / \mathbf{M n}$ & $\mathbf{C} / \mathbf{M n}$ \\
\hline $0.42-N a-H-B u s$ & 0.01 & 0.05 & 1.86 & 9.55 & 0.005 & 0.195 \\
0.52-Na-H-Bus & 0.02 & 0.04 & 2.34 & 8.56 & 0.005 & 0.273 \\
0.67-Na-H-Bus & 0.01 & 0.04 & 2.43 & 7.64 & 0.005 & 0.318 \\
0.52-K-H-Bus & 0 & 0.26 & 1.82 & 7.78 & 0.033 & 0.234 \\
0.52-H-Bus & 0.02 & 0.11 & 1.00 & 9.13 & 0.012 & 0.110 & 0.554 \\
\hline
\end{tabular}

* Equivalent charge of metal ions per $\mathrm{Mn}$.

XRD patterns at reflux times of $48-72 \mathrm{~h}$. As the reflux time is extended to 1 month, the birnessite peaks disappear and the characteristic peaks of todorokite become much stronger, while peaks of low-valence manganite $(\gamma-\mathrm{MnOOH}$, JPCDS 8-99) are observed (Figure 4b). When the $\mathrm{Mn}(\mathrm{VII}) / \mathrm{Mn}$ (II) ratio increases to 0.67 , only the characteristic peaks of birnessite are observed at a reflux time of $72 \mathrm{~h}$, indicating that todorokite is not formed. At a reflux time of 1 month, the weak characteristic peaks of todorokite are visible with similar intensity to those of birnessite, suggesting that part of the $0.67-\mathrm{Na}$ $\mathrm{H}$-Bus has been converted to todorokite (Figure 4c).

Furthermore, it is also observed that $0.52-\mathrm{K}-\mathrm{H}-\mathrm{Bus}$ and $0.52-\mathrm{H}$-Bus after reflux treatment are partially transformed into todorokite but to a lesser extent compared to $0.52-\mathrm{Na}-\mathrm{H}-\mathrm{Bus}$, the corresponding $\mathrm{Na}^{+}$preexchanged precursor. The intensities of the characteristic peaks of todorokite and birnessite in the XRD pattern of 0.52-K-H-Bus after reflux for $72 \mathrm{~h}$ (Figure $4 \mathrm{~d}$ ) are close to those of $0.52-\mathrm{Na}-\mathrm{H}-\mathrm{Bus}$ refluxed for $48 \mathrm{~h}$ (Figure $4 \mathrm{~b}$ ). This suggests that $0.52-\mathrm{K}-\mathrm{H}-\mathrm{Bus}$ is less favorable for the transformation than 0.52-Na-H-Bus. When 0.52-H-Bus (without $\mathrm{Na}^{+}$or $\mathrm{K}^{+}$pre-exchange treatment) is refluxed for $3 \mathrm{~h}$, the characteristic peaks of ramsdellite $(1 \times 2$ tunnel-structured $\gamma-\mathrm{MnO}_{2}$, JPCDS 44-0142) appear, while very weak XRD reflections of todorokite can be discerned after $12 \mathrm{~h}$. With increasing reflux time, the intensities of the peaks of todorokite and those of ramsdellite remain nearly unchanged (Figure 4e).

After $72 \mathrm{~h}$ reflux treatment of $0.42-\mathrm{Na}-\mathrm{H}-\mathrm{Bus}$, the formed todorokite consists of well-crystallized laths aggregating laterally across the (100) direction, measuring $\sim 12-30 \mathrm{~nm}$ in width and $\sim 70-500 \mathrm{~nm}$ in length along the $(010)$ direction (Figure 5a). The main lattice fringe spacing along the (100) direction, i.e. the tunnel width, is $0.96 \mathrm{~nm}$ (Figure $5 \mathrm{~b}$ ), equivalent to three $\mathrm{MnO}_{6}$ octahedral chain widths. In addition, spacings of 0.6 and $1.6 \mathrm{~nm}$, corresponding to two and four $\mathrm{MnO}_{6}$ octahedral widths are also observed, which is consistent with the reported by Atkins et al. [15]. This phenomenon of tunnel-width inconsistencies are commonly observed in natural and synthesized todorokite samples [11, 30-33]. The morphology of $0.52-\mathrm{Na}-\mathrm{H}$-Bus after reflux treatment for $72 \mathrm{~h}$ is dominated by elongated fibers $(\sim 5 \mu \mathrm{m})$ of crystalline todorokite (not shown). These fibers appear to be aggregated into a dense network of fibers within a plate-like matrix (Figure 5c). The overlapping fibers are aligned with each other at $120^{\circ}$ (Figure 5c), which is a characteristic morphology of the trilling pattern of todorokite. The lattice fringe spacings are 0.96 and $0.48 \mathrm{~nm}$ (Figure $5 \mathrm{~d}$ ). For $0.67-\mathrm{Na}-\mathrm{H}$-Bus after reflux treatment for $72 \mathrm{~h}$, small fibrous needles can be seen to be intergrown within the platy matrix (Figure 5e). Lattice fringe spacings of 0.96 and $0.72 \mathrm{~nm}$ can be observed (Figure 5f), implying that this sample may contain two phases of birnessite and todorokite. However, its XRD pattern does not show discernible reflections of todorokite, and so the content of todorokite maybe too small to be detected by XRD.

FTIR spectroscopy can conclusively distinguish between layer-type birnessite and tunnel-type todorokite $[15,34]$, because the broad peak at $\sim 760 \mathrm{~cm}^{-1}$ in FTIR of $\mathrm{Mn}$ oxides is typically assigned to an asymmetrical $\mathrm{Mn}-\mathrm{O}$ stretching vibration, corresponding to cornersharing $\mathrm{MnO}_{6}$ octahedra, which is absent in phyllomanganate Mn oxides [34]. Figure 3b shows FTIR spectra of "c-disordered" $\mathrm{Na}$-H-birnessites after Mg-exchange and reflux treatment for $72 \mathrm{~h}$. Besides the common bands of Mn oxides at 438, 517, and $558 \mathrm{~cm}^{-1}$, the characteristic peak of todorokite at $\sim 762 \mathrm{~cm}^{-1}$ can be observed with decreasing intensities from $0.42-\mathrm{Na}-\mathrm{H}$-Bus $72 \mathrm{~h}$ reflux to $0.52-\mathrm{Na}-\mathrm{H}$-Bus $72 \mathrm{~h}$ reflux to $0.67-\mathrm{Na}-\mathrm{H}-\mathrm{Bus} 72 \mathrm{~h}$ reflux (Figure $3 \mathrm{~b}$ ). This result suggests that these " $c$-disordered" $\mathrm{Na}-\mathrm{H}$-birnessites are converted into todorokite to different extents after reflux treatment, and low Mn AOS is favorable to the transformation. This conclusion agrees very well with the XRD and TEM analyses (Figures 4, 5).

\section{Discussion}

\section{The effect of interlayer $\mathrm{Na}^{+}$and $\mathrm{K}^{+}$on the formation of tectomanganates}

It is believed that a small amount of cations such as $\mathrm{Ca}^{2+}$, $\mathrm{Mg}^{2+}, \mathrm{Ni}^{2+}, \mathrm{Li}^{+}, \mathrm{Na}^{+}, \mathrm{K}^{+}, \mathrm{NH}_{4}^{+}$, or $\mathrm{H}_{3} \mathrm{O}^{+}$is required to stabilize the tunnels in the formation of tectomanganates [35-37]. The order of hydrated radii of interlayer ions is $\mathrm{K}^{+}(3.31 \AA)<\mathrm{Na}^{+}(3.58 \AA)<\mathrm{Mg}^{2+}(4.28 \AA)$. After the " $c$-disordered" $\mathrm{H}^{+}$-birnessite samples had been 

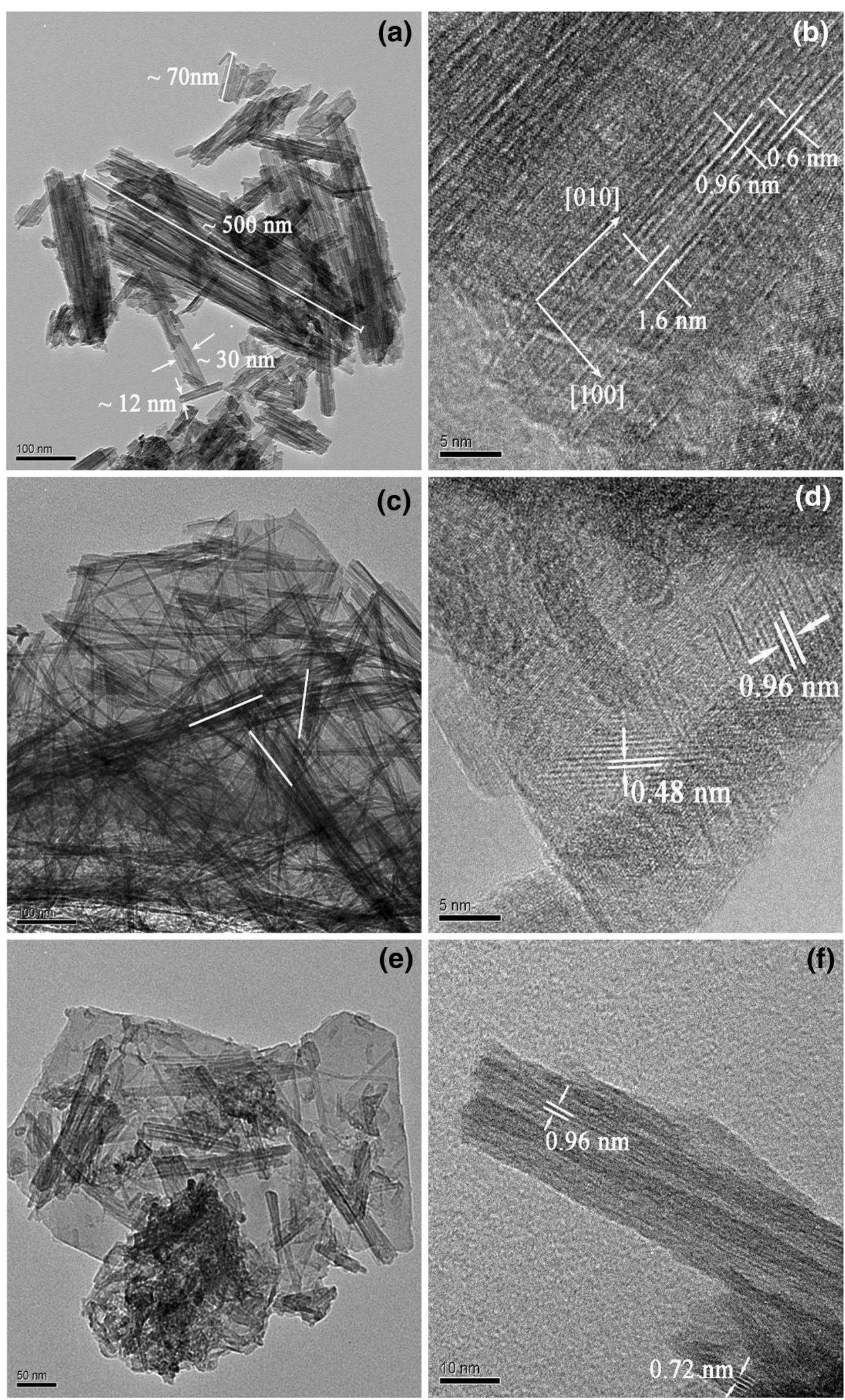

Figure 5 HR-TEM images of " $\mathrm{C}$-disordered" $\mathrm{Na}$-H-birnessites with different $\mathrm{Mn}(\mathrm{VII}) / \mathrm{Mn}$ (II) ratios after Mg-exchange and reflux treatment for $72 \mathrm{~h}$. $\mathbf{a}$, b 0.42-Na-H-Bir; c, d 0.52-Na-H-Bir; e, f 0.67-Na-H-Bir. 
exchanged with $\mathrm{Mg}^{2+}$ for $24 \mathrm{~h}$, most of the interlayer $\mathrm{Na}^{+}$ was replaced by $\mathrm{Mg}^{2+}$ (Table 2). Only part of the interlayer $\mathrm{K}^{+}$was replaced by $\mathrm{Mg}^{2+}$ in the $0.52-\mathrm{K}-\mathrm{H}$-Bus sample, probably caused by stronger electrostatic interaction between $\mathrm{K}^{+}$with smaller hydrated radius and negative $\mathrm{MnO}_{6}$ octahedral layers compared with $\mathrm{Na}^{+}$and $\mathrm{Mg}^{2+}$. The transformation from $0.52-\mathrm{K}-\mathrm{H}-\mathrm{Bus}$ to todorokite is slower than that from $0.52-\mathrm{Na}-\mathrm{H}-\mathrm{Bus}$, which can be attributed to the fact that the interlayer $\mathrm{K}^{+}$of $0.52-\mathrm{K}-\mathrm{H}-$ Bus cannot be completely exchanged with $\mathrm{Mg}^{2+}$, and the remaining $12.6 \%$ of interlayer $\mathrm{K}^{+}$inhibits transformation of buserite to todorokite.

Under reflux treatment at $100^{\circ} \mathrm{C}, 0.52-\mathrm{H}$-Bus is transformed into ramsdellite, while $\mathrm{Na} / \mathrm{K}-\mathrm{H}$-buserites are transformed into todorokite. This significant difference may be ascribed to different contents of interlayer ions in their precursors. The levels of $\mathrm{Mg}^{2+}$ and $\mathrm{K}^{+}$in the interlayer of $0.52-\mathrm{H}$-Bus are 0.110 and 0.012 in molar ratios of $\mathrm{Mg} / \mathrm{Mn}$ and $\mathrm{K} / \mathrm{Mn}$, or 0.233 equivalent charge of cations per Mn atom (Table 2). These values are much lower than the levels in 0.52-Na-H-Bus (0.273 and 0.005, or 0.554 ) and $0.52-\mathrm{K}-\mathrm{H}-\mathrm{Bus}(0.234$ and 0.033 , or 0.501$)$. Given the close $\mathrm{MnO}_{6}$ layer structures of $0.52-\mathrm{Na}-\mathrm{H}-\mathrm{Bus}$, $0.52-\mathrm{K}-\mathrm{H}$-Bus, and 0.52-H-Bus, it can be inferred that a substantial part of the negative layer charge of $0.52-\mathrm{H}-$ Bus is also electrostatically balanced by $\mathrm{H}^{+}$, either structurally bound or free in interlayers, apart from $\mathrm{Mg}^{2+}$ and $\mathrm{K}^{+}$ions in the interlayers. Because of the smaller hydrated radius of $\mathrm{H}^{+}(2.82 \AA)$ compared to $\mathrm{K}^{+}, \mathrm{Na}^{+}$, and $\mathrm{Mg}^{2+}$, the interaction between $\mathrm{H}^{+}$and birnessite layers is supposed to be the greatest, which can account for the lower $\mathrm{Mg}^{2+}$ content of $0.52-\mathrm{H}$-Bus in comparison with 0.52-K-H-Bus and 0.52-Na-H-Bus (Table 2). Ramsdellite has a $1 \times 2$ tunnel structure, which is constructed of double chains of octahedra linked with single octahedral units by sharing corner oxygen atoms to form a rectangular cross-section [9]. Waychunas [38] reported that the tunnels of ramsdellite are normally empty but trace amounts of water, $\mathrm{Na}$, and $\mathrm{Ca}$ might be present in the tunnels. Todorokite has a $3 \times 3$ tunnel structure with corner-sharing triple chains of $\mathrm{MnO}_{6}$ octahedra that are saturated with different larger cations such as $\mathrm{Mg}^{2+}$, $\mathrm{Ca}^{2+}$, and $\mathrm{Ni}^{2+}$ [3]. The large tunnels $(6.9 \times 6.9 \AA)$ make todorokite materials possess a high ion-exchange capacity [4]. Therefore, lower contents of interlayer metal ions can account for the transformation of " $c$-disordered" $\mathrm{H}^{+}$-birnessite to ramsdellite with a smaller tunnel size of $1 \times 2$ rather than todorokite.

\section{The role of Mn AOS in transformation of "c-disordered" $\mathrm{H}^{+}$-birnessite into todorokite}

The results show that from $0.42-\mathrm{Na}-\mathrm{H}-\mathrm{Bus}$ to $0.52-\mathrm{Na}-\mathrm{H}-$ Bus to $0.67-\mathrm{Na}-\mathrm{H}$-Bus, increasing reflux treatment time is required for both todorokite appearance and complete formation (Figure 4). In other words, "c-disordered" $\mathrm{H}^{+}$birnessites with small Mn AOS values are readily transformed into todorokite, which is consistent with triclinic birnessite transformation to todorokite [8]. When $\mathrm{Mg}^{2+}$ exchanged " $c$-disordered" $\mathrm{H}^{+}$-birnessite is refluxed at $100^{\circ} \mathrm{C}$, the $\mathrm{Mn}(\mathrm{III})$ species may easily move from the layers of buserite to the interlayer, leaving more vacancies in the buserite framework. Subsequently more interlayer $\mathrm{Mn}$ (III) species can gradually bond through covalence via condensation and dehydration reactions with each other and structural rearrangement to construct the "walls" of the tunnels. At this time, if the content and type of interlayer cations are sufficient to stabilize the 1-nm interlayer spacing, todorokite with 1-nm tunnel size will gradually form. Otherwise if the interlayer cations possess small hydrated radii, such as $\mathrm{Na}^{+}, \mathrm{K}^{+}$, or are present in insufficient amounts, such as in the case of 0.52-H-Bus, the 1-nm interlayer spacing will collapse and the shorter tunnel "walls" may be built instead. This leads to formation of tectomanganates with small size tunnels, for instance, cryptomelane with $2 \times 2$ size [39], ramsdellite with $1 \times 2$ size, or even pyrolusite with $1 \times 1$ size [40].

In addition, a sufficient amount of large interlayer cations does not necessarily facilitate the formation of todorokite if the Mn AOS of the precursor birnessite is high enough or there is insufficient $\mathrm{Mn}$ (III) species. After $\mathrm{Mg}^{2+}$-exchange for $24 \mathrm{~h}$, the $\mathrm{Mg}^{2+}$ content of $\mathrm{Na}$ $\mathrm{H}$-Bus increases with increasing $\mathrm{Mn}(\mathrm{VII}) / \mathrm{Mn}(\mathrm{II})$ ratio in the synthesis of " $c$-disordered" $\mathrm{H}$-birnessite (Table 2). This is probably because the $\mathrm{Na}-\mathrm{H}$-birnessite with large Mn AOS contains more vacancy sites [41, 42], and so more negative layer charge will develop and more $\mathrm{Mg}^{2+}$ is needed to reach charge equilibrium. However, the extent and rate of transformation into todorokite sharply decreases with increasing $\mathrm{Mg}$ content from 0.42-Na$\mathrm{H}$-Bus to 0.52- $\mathrm{Na}-\mathrm{H}-\mathrm{Bus}$ to 0.67- $\mathrm{Na}-\mathrm{H}$-Bus (Figure 4; Table 2).

It should be noted that " $c$-disordered" $\mathrm{H}^{+}$-birnessite is more difficult to convert to todorokite compared to triclinic birnessite with similar Mn AOS value under the same reflux conditions. For instance, triclinic birnessite with Mn AOS of 3.58 (0.33-Na-bir) can be almost completely converted into todorokite within $24 \mathrm{~h}$ [8], while it will take $48 \mathrm{~h}$ for complete conversion of $0.42-\mathrm{Na}-\mathrm{H}-\mathrm{Bir}$ with Mn AOS of 3.55. One explanation for this could be that greater structural adjustment may be required for "c-disordered" $\mathrm{H}^{+}$-birnessite, a type of hexagonal birnessite, to be converted into todorokite relative to triclinic birnessite. Our other experiments showed that hexagonal birnessites, either $\delta-\mathrm{MnO}_{2}$ or acid birnessite, with high Mn AOS of 3.85 are barely converted into todorokite after $\mathrm{Mg}^{2+}$ exchange and reflux treatment (data not 
shown). After reacting with low-concentration aqueous $\mathrm{Mn}(\mathrm{II})$, these hexagonal birnessites can gradually transform into birnessites with a orthogonal layer symmetry, and the produced birnessites can be completely converted into todorokite after $24 \mathrm{~h}$ of reflux treatment. This result confirms that triclinic birnessite with orthogonal layer is more likely than hexagonal birnessite to be converted into todorokite. Thus, triclinic birnessite had been exclusively used to prepare todorokite in the laboratory in the previous literature until recently Atkins et al. [15] reported successful synthesis of todorokite using " $c$-disordered" $\mathrm{H}^{+}$-birnessite as the precursor.

Ideal hexagonal birnessite hardly contains $\mathrm{Mn}(\mathrm{III})$, i.e. it has high Mn AOS but a large number of vacancy sites (16.7\%), contrarily ideal triclinic birnessite barely possesses vacancy sites but does have a large amount of $\operatorname{Mn}(\mathrm{III})(33.3 \%)$ [17, 23, 43]. In this study, with decreasing Mn AOS the layer structure of "c-disordered" birnessite may adjust gradually towards that of triclinic birnessite, in other words, "c-disordered" birnessite with low Mn AOS may modify its structure, at least partially, towards triclinic birnessite through layer symmetry adjustment. These will definitely facilitate their transformation to todorokite. Further study is needed to explore the pathway of todorokite formation and whether triclinic birnessite is the necessary intermediate during the transformation of hexagonal birnessite into todorokite.

Therefore, Mn(III) together with content and type of interlayer metal ions plays a crucial role in the transformation of " $c$-disordered" $\mathrm{H}^{+}$-birnessite with hexagonal symmetry to todorokite, which is also the case for the triclinic birnessite transformation [8]. These results provide a further explanation for the common occurrence of todorokite in the hydrothermal ocean environment [32, 44], where is usually enriched in large metal ions such as $\mathrm{Mg}, \mathrm{Ca}, \mathrm{Ni}$, Co and etc., and plenty of $\mathrm{Mn}(\mathrm{II})$ released from hydrothermal activity. This $\mathrm{Mn}(\mathrm{II})$ can easily cause $\mathrm{Mn}$ (III) formation in birnessite, either with orthogonal or hexagonal layer symmetry.

\section{Conclusions}

The transformation of a layered birnessite to a tunnelstructure todorokite is a complex process. From the above results it is evident that the phase transformation of layer-structure " $c$-disordered" $\mathrm{H}^{+}$-birnessite to tunnelstructure todorokite is greatly affected by the amount of $\mathrm{Mn}$ (III) and the type and content of interlayer cations in the birnessite. Under reflux conditions, the degree of transformation of " $c$-disordered" $\mathrm{H}^{+}$-birnessite to todorokite decreases significantly as the Mn AOS values of Na-H-birnessite increase from 3.58 to 3.74. The transformation from $\mathrm{K}-\mathrm{H}$-birnessite to todorokite is slower than that from $\mathrm{Na}-\mathrm{H}$-birnessite, because the interlayer
$\mathrm{K}^{+}$of birnessite cannot be completely exchanged with $\mathrm{Mg}^{2+}$, and so interlayer $\mathrm{K}^{+}$inhibits transformation of birnessite to todorokite. " $c$-disordered" $\mathrm{H}^{+}$-birnessite contained lower levels of $\mathrm{Na} / \mathrm{K}$ is transformed into ramsdellite rather than todorokite.

\section{Authors' contributions}

$\mathrm{HZ}$ and $\mathrm{XL}$ carried out the mineral preparation and cleaning protocols. $\mathrm{HZ}$ conducted the XRD, HRTEM, and IR analysis. XF conceived the study and helped with the analysis of the results. All authors were involved in discussing and interpreting the results, as well as in editing and commenting on the draft manuscript. All authors read and approved the final manuscript.

\section{Acknowledgements}

The authors acknowledge the National Natural Science Foundation of China (Grant Nos. 41471194 \& 41171197), and the Program for the Yangtze River Scholar and Innovative Research Team at the University of China (IRT1247) for financial support of this research.

\section{Compliance with ethical guidelines}

\section{Competing interests}

The authors declare that they have no competing interests.

Received: 30 January 2015 Accepted: 28 June 2015

Published online: 15 July 2015

\section{References}

1. Turner S, Buseck PR (1981) A new family of naturally occurring manganese oxides. Science 212:1024-1027

2. Bolton BR, Ostwald J, Monzier M (1986) Precious metals in ferromanganese crusts from the south-west pacific. Nature 320:518-520

3. Yin YG, Xu WQ, Shen YF, Suib SL (1994) Studies of oxygen species in synthetic todorokite-like manganese oxide octahedral molecular sieves. Chem Mater 6:1803-1808

4. Shen YF, Zerger RP, DeGuzman RN, Suib SL, McCurdy L, Potter DI et al (1993) Manganese oxide octahedral molecular sieves: preparation, characterization, and applications. Science 260(5107):511-515

5. Vileno E, Ma Y, Zhou H, Suib SL (1998) Facile synthesis of synthetic todorokite (OMS-1), co-precipitation reactions in the presence of a microwave field. Micropor Mesopor Mat 20:3-15

6. Ching S, Krukowska KS, Suib SL (1999) A new synthetic route to todorokite-type manganese oxides. Inorg Chim Acta 294:123-132

7. Feng Q, Kanoh H, Ooi K (1999) Manganese oxide porous crystals. J Mater Chem 9:319-333

8. Cui HJ, Qiu GH, Feng XH, Tan WF, Liu F (2009) Birnessites with different average manganese oxidation states synthesized, characterized, and transformed to todorokite at atmospheric pressure. Clays Clay Miner 57(6):715-724

9. Post JE (1999) Manganese oxide minerals: crystal structures and economic and environmental significance. Proc Natl Acad Sci 96:3447-3454

10. Golden DC, Ghen CC, Dixon JB (1986) Synthesis of todorokite. Science 231:717-719

11. Feng XH, Tan WF, Liu F, Wang JB, Ruan HD (2004) Synthesis of todorokite at atmospheric pressure. Chem Mater 16(22):4330-4336

12. Mellin TA, Lei G (1993) Stabilization of $10 \AA$-manganates by interlayer cations and hydrothermal treatment: Implications for the mineralogy of marine manganese concretions. Mar Geol 115:67-83

13. Liu J, Cai J, Son YC, Gao QM, Suib SL, Aindow M (2002) Magnesium manganese oxide nanoribbons: Synthesis, characterization, and catalytic application. J Phys Chem B 106(38):9761-9768

14. Cui HJ, Liu XW, Tan WF, Feng XH, Liu F, Daniel RH (2008) Influence of $\mathrm{Mn}(\mathrm{III})$ availability on the phase transformation from layered buserite to tunnel-structured todorokite. Clays Clay Miner 56(4):397-403 
15. Atkins AL, Shaw S, Peacock CL (2014) Nucleation and growth of todorokite from birnessite: Implications for trace-metal cycling in marine sediments. Geochim Cosmochim Acta 144:109-125

16. Bargar JR (2005) Biotic and abiotic products of $\mathrm{Mn}(\mathrm{II})$ oxidation by spores of the marine Bacillus sp. strain SG-1. Am Mineral 90(1):143-154

17. Villalobo M, Toner B, Bargar J, Sposito G (2003) Characterization of the manganese oxide produced by Pseudomonas putida strain MnB1. Geochim Cosmochim Acta 67(14):2649-2662

18. Saratovsky L, Wightman PG, Pasten PA, Gaillard GF, Poeppelmeier KR (2006) Manganese oxides: parallels between abiotic and biotic structure J Am Chem Soc 128:11188-11198

19. Spiro TG, Bargar JR, Sposito G, Tebo BM (2010) Bacteriogenic manganese oxides. Accounts Chem Res 43(1):2-9

20. Feng XH, Zhu MQ, Ginder-Vogel M, Ni CY, Parikh SJ, Sparks DL (2010) Formation of nano-crystalline todorokite from biogenic Mn oxides. Geochim Cosmochim Acta 74(11):3232-3245

21. Bish DL, Post JE (1989) Thermal behavior of complex, tunnel-structure manganese oxides. Am Mineral 74(1-2):177-186

22. Drits VA, Silvester E, Gorshkov Al, Manceau A (1997) Structure of monoclinic Na-rich birnessite and hexagonal birnessite I. Results from X-ray diffraction and selected-area electron diffraction. Am Mineral 82:946-961

23. Drits VA, Lanson B, Gaillot AC (2007) Birnessite polytype systematics and identification by powder X-ray diffraction. Am Mineral 92(5-6):771-788

24. Villalobos M, Lanson B, Manceau A, Toner B, Sposito G (2006) Structural model for the biogenic Mn oxide produced by Pseudomonas putida. Am Mineral 91(4):489-502

25. Grangeon S, Manceau A, Guilhermet J, Gaillot A-C, Lanson M, Lanson B (2012) Zn sorption modifies dynamically the layer and interlayer structure of veradite. Geochim Cosmochim Acta 85:302-313

26. Manceau A, Marcus MA, Grangeon S, Lanson M, Lanson B, Gaillot A-C et al (2013) Short-range and long-range order of phyllomanganate nanoparticles determined using high-energy X-ray scattering. J Appl Cryst 46:193-209

27. Potter RM, Rossman GR (1979) The tetravalent manganese oxides: identification, hydration, and structural relationships by infrared spectroscopy. Am Mineral 64:1199-1218

28. Luo J, Zhang QH, Huang AM, Giraldo O, Suib SL (1999) Double-aging method for preparation of stabilized Na buserite and transformations to todorokite incorporated with various metals. Inorg Chem 38:6106-6113

29. Feng XH, Tan WF, Liu F, Huang QY, Liu XW (2005) Pathways of birnessite formation in alkali medium. Sci China Ser D 48(9):1438

30. Kang L, Zhang M, Liu ZH, Ooi K (2007) IR spectra of manganese oxides with either layered or tunnel structures. Spectrochim Acta Part A 67(3-4):864-869
31. Turner S, Siegel MD, Buseck PR (1982) Structural feature of todorokite intergrowths in manganses nodules. Nature 296:841-842

32. Bodeï S, Manceau A, Geoffroy N, Baronnet A, Buatier M (2007) Formation of todorokite from vernadite in Ni-rich hemipelagic sediments. Geochim Cosmochim Acta 71(23):5698-5716

33. Xu HF, Chen TH, Konishi H (2010) HRTEM investigation of trilling todorokite and nano-phase Mn-oxides in manganese dendrites. Am Mineral 95(4):556-562

34. Julien CM, Massot M, Poinsignon C (2004) Lattice vibrations of manganese oxides. Part I. Periodic structures. Spectrochim Acta Part A 60(3):689-700

35. Brock SL, Duan NG, Tian ZR, Giraldo O, Zhou H, Suib SL (1998) A review of porous manganese oxide materials. Chem Mater 10:2619-2628

36. Shen YF, Suib SL, O'Young CL (1994) Effects of inorganic cation templates on octahedral molecular sieves of manganese oxide. J Am Chem Soc 116:11020-11029

37. Reddy RN, Reddy RG (2003) Sol-gel $\mathrm{MnO}_{2}$ as an electrode material for electrochemical capacitors. J Power Sources 124(1):330-337

38. Waychunas GA (1991) Crystal chemistry of oxides and oxyhydroxides. Rev Mineral Geochem 25:11-68

39. Grangeon S, Lanson B, Lanson M (2014) Solid-state transformation of nanocrystalline phyllomanganate into tectomanganate: influence of initial layer and interlayer structure. Acta Crystallogr B 70(Pt 5):828-838

40. DeGuzman RN, Shen YF, Neth EJ, Suib SL, O'Young CL, Levine $\mathrm{S}$ et al (1994) Synthesis and characterization of octahedral molecular OMS-2. Chem Mater 6:815-821

41. Zhao W, Cui HJ, Liu F, Tan WF, Feng XH (2009) Relationship between Pb²+ adsorption and average $\mathrm{Mn}$ oxidation state in synthetic birnessites. Clays Clay Miner 57(5):513-520

42. Wang $Y$, Feng $X H$, Villalobos $M$, Tan WF, Liu F (2012) Sorption behavior of heavy metals on birnessite: Relationship with its Mn average oxidation state and implications for types of sorption sites. Chem Geol 292-293:25-34

43. Lanson B, Drits VA, Silvester E, Manceau A (2000) Structure of $\mathrm{H}$-exchanged hexagonal birnessite and its mechanism of formation from Na-rich monoclinic buserite at low pH. Am Mineral 85:826-838

44. Bargar JR, Fuller CC, Marcus MA, Brearley AJ, Perez De la Rosa M, Webb SM (2009) Structural characterization of terrestrial microbial Mn oxides from Pinal Creek AZ. Geochim Cosmochim Acta 73(4):889-910

\section{Publish with ChemistryCentral and every scientist can read your work free of charge \\ "Open access provides opportunities to our colleagues in other parts of the globe, by allowing anyone to view the content free of charge."}

W. Jeffery Hurst, The Hershey Company.

- available free of charge to the entire scientific community

- peer reviewed and published immediately upon acceptance

- cited in PubMed and archived on PubMed Central

- yours - you keep the copyright

Submit your manuscript here:

$\mathrm{http}: / / \mathrm{www}$. chemistrycentral.com/manuscript/ 